\title{
Long-term antihypertensive drug treatment and blood pressure control in three hospital hypertension clinics
}

\author{
L J BEILIN, * C J BULPITT, E C COLES, C T DOLLERY, J S S GEAR, \\ G HARPER, B F JOHNSON, A D MUNRO-FAURE, S C TURNER
}

From the Department of the Regius Professor of Medicine, Oxford; the Department of Clinical Pharmacology, Royal Postgraduate Medical School, London; the Department of Renal Medicine, King's College Hospital, London; and Division of Computing and Statistics, The Clinical Research Centre, Harrow, Middlesex

SUMMARY Prescribing patterns and blood pressure control have been studied in 1101 patients treated at three specialist hypertension clinics in Britain. Seventy-four per cent of the patients were already receiving treatment at the time they were referred by their general practitioners. Though the initial improvement in blood pressure control was satisfactory, there was often some deterioration of control over the long term. The pressure exceeded $140 / 90 \mathrm{mmHg}$ in the majority of patients followed for a year or more. During 1971-5 diuretics remained first preference, with increasing use of beta-blockers and a distinct decline in the use of sympathetic neurone blockers both by hospital staff and referring practitioners. Multiple drug treatment was common, nearly half the patients requiring more than one antihypertensive drug. In newly treated patients the frequency of cessation of a particular class of drug because of side effects or lack of efficacy ranged from 6 per cent with diuretics to 57 per cent with adrenergic neurone blocking drugs. Long-term blood pressure control still presents many problems, and the results contrast with the more optimistic interpretations sometimes placed on short-term clinical trials of antihypertensive effect.

Clinical trials carried out in the early stages of evaluation of new antihypertensive drugs often last only a few weeks or at most a few months. Frequently the number of patients involved is small. In Britain the Committee on Safety of Medicines requires that 100 patients shall have been treated for more than a year with a new antihypertensive agent before it is marketed, but this is an unusually stringent requirement. Not surprisingly, after the introduction of compounds into day-to-day practice antihypertensive drugs are often shown in a different perspective than in clinical trials.

To investigate some of the problems of long-term antihypertensive drug treatment we have analysed blood pressure control and drug usage in 1101 patients treated for up to five years at three hypertension clinics in the United Kingdom.

\section{Subjects and methods}

Analyses were carried out on patients newly referred to and treated at hypertension clinics at Hammer-

^Present address: University Department of Medicine, Royal Perth Hospital, Perth, Western Australia 6000.

Received for publication 17 July 1979 smith Hospital, London, the Radcliffe Infirmary, Oxford, and King's College Hospital, London, between May 1971 and April 1975. The last patient entered in 1975 was studied until April 1976, so that the maximum period of follow-up was five years and the minimum period was one year. Clinical and laboratory data were recorded at each visit using a computer-based medical record. ${ }^{1-4}$

\section{TREATMENT CATEGORIES}

'Previously treated' patients were defined as those who had received antihypertensive drugs within three months before their initial visit; 'previously untreated' patients had received no such treatment.

\section{ANTIHYPERTENSIVE DRUGS}

Agents defined as antihypertensive drugs included all diuretics, beta-adrenergic receptor blocking agents, alpha-methyldopa, clonidine, reserpine, and rauwolffia alkaloids, the vasodilator hydralazine, and the adrenergic neurone blockers guanethidine, debrisoquine, and bethanidine. Analyses were carried out for specific drugs as well as for groups of compounds with similar modes of action. 


\section{CHOICE OF DRUGS}

The first antihypertensive drug, or the first two drugs prescribed simultaneously were regarded as 'first choice' or 'first choice equal', respectively.

\section{DRUGS STOPPED}

'Cessation of a drug' was defined as stopping one drug permanently, without prescribing another in the same pharmacological group. Thus stopping a beta-blocker and starting a diuretic would be regarded as cessation of beta-blocker treatment, whereas substituting one beta-blocker for another would not.

\section{BLOOD PRESSURES}

Blood pressures were recorded by standard mercury sphygmomanometry. At the first visit to the clinic blood pressures were recorded with the patient supine after a few minutes' rest, after one minute in the sitting position, and finally after two minutes standing. At follow-up visits patients at Hammersmith Hospital had pressures recorded supine and standing, while at the Radcliffe Infirmary pressures were recorded with the patient sitting and standing. Unless otherwise stated, control was assessed for blood pressures recorded in the standing position, as these were available for all three clinics. The average of pressures over three- and six-month intervals was calculated for each patient, starting at the visit after treatment was begun (or after the first visit for 'previously treated' patients). These averages were used for group means, or for determining the numbers of patients whose systolic or diastolic pressures fell within a particular range.

\section{Results}

POPULATION STUDIED

Analyses were carried out on 499 patients at the Radcliffe Infirmary, 453 at Hammersmith Hospital, and 149 at King's College Hospital. Of these patients, 817 were already receiving treatment on referral.

\section{BLOOD PRESSURE CONTROL}

Group mean blood pressures for the first four consecutive three-monthly periods on treatment are shown in Table 1. Initial pressures and subsequent control were similar for the three clinics.

Blood pressure control was further assessed by calculating the percentage of patients whose average pressures fell in different ranges. As patients were followed in the clinics for varying periods of time, this analysis was performed on cohorts followed for at least 12 months and seen at least once in the first and second three-month period and during the
Table 1 Blood pressure control (combined clinics)

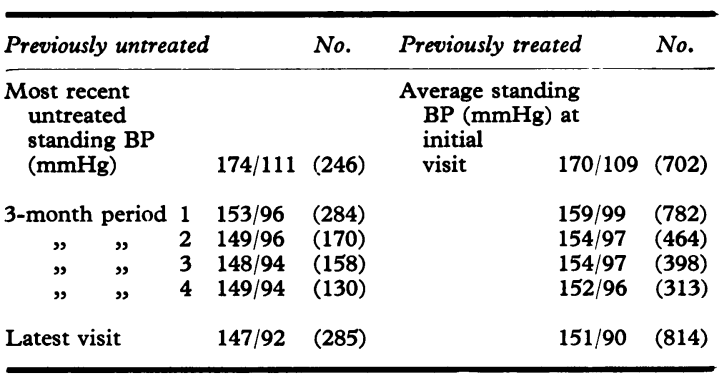

The variable numbers of patients in each period reflect the variations in duration and frequency of attendance.

subsequent six months after starting treatment (Tables 2 and 3 ).

Blood pressures of previously treated patients were generally higher on referral (Table 3) than those of patients who had previously received no treatment (Table 2).

The main fall in pressure occurred during the first three months of treatment. Subsequently there

Table 2 Blood pressure control in 126 previously untreated patients

\begin{tabular}{lllll}
\hline $\begin{array}{l}\text { Pressure } \\
\text { range } \\
(\text { mmHg) }\end{array}$ & $\begin{array}{l}\text { Pretreatment } \\
(\%)\end{array}$ & $\begin{array}{l}\text { First three } \\
\text { months } \\
(\%)\end{array}$ & $\begin{array}{l}\text { Second three } \\
\text { months } \\
(\%)\end{array}$ & $\begin{array}{l}\text { Six to 12 } \\
\text { months } \\
(\%)\end{array}$ \\
\hline $\begin{array}{c}\text { Systolic } \\
<140\end{array}$ & 2 & 58 & 35 & \\
$140-169$ & 37 & 26 & 51 & 33 \\
$170-199$ & 37 & 14 & 13 & 55 \\
$\geqslant 200$ & 25 & 2 & 1 & 11 \\
& & & & 1 \\
Diastolic & & 49 & 19 & \\
$<90$ & 1 & 30 & 56 & 31 \\
$90-104$ & 18 & 20 & 22 & 99 \\
$105-119$ & 48 & 1 & 2 & 2 \\
$\geqslant 120$ & 33 & & & \\
\hline
\end{tabular}

Each patient was seen at least once during each period.

Table 3 Blood pressure control in 401 previously treated patients

\begin{tabular}{lllll}
\hline $\begin{array}{l}\text { Pressure } \\
\text { range } \\
(\text { mmHg })\end{array}$ & $\begin{array}{l}\text { On referral } \\
(\%)\end{array}$ & $\begin{array}{l}\text { First three } \\
\text { months } \\
(\%)\end{array}$ & $\begin{array}{l}\text { Second three } \\
\text { months } \\
(\%)\end{array}$ & $\begin{array}{l}\text { Six to 12 } \\
\text { months } \\
(\%)\end{array}$ \\
\hline $\begin{array}{c}\text { Systolic } \\
<140\end{array}$ & 14 & 38 & 32 & 29 \\
$140-169$ & 26 & 36 & 44 & 49 \\
$170-199$ & 33 & 21 & 19 & 18 \\
$\geqslant 200$ & 27 & 6 & 5 & 3 \\
& & & & \\
Diastolic & 10 & 37 & 20 & 24 \\
$<90$ & 10 & 28 & 51 & 54 \\
$90-104$ & 25 & 27 & 23 & 20 \\
$105-119$ & 31 & 8 & 6 & 2 \\
$\geqslant 120$ & 34 & & & \\
\hline
\end{tabular}

Each patient was seen at least once during each period. 
was deterioration in control in the third to sixth month, with little change thereafter. A similar loss of early blood pressure control was found when data for the entire population were analysed, though there were fewer regular observations on some of these patients. The latest recorded pressures of 25 previously untreated patients discharged within six months of first attendance averaged $161 / 100 \pm \mathrm{SD} 34 \cdot 2 / 14 \cdot 7 \mathrm{mmHg}$ compared with $143 / 89 \pm$ SD $20 \cdot 4 / 16.2 \mathrm{mmHg}$ in 199 patients followed for 12 months or more.

\section{DRUG TREATMENT AND BLOOD PRESSURE CONTROL}

The relation between individual drugs and blood pressure control was assessed by calculating the averages of both initial and latest blood pressures according to the drugs taken for the last three months of attendance. The mean of all pressures available (standing, sitting, lying) at a visit was used for these calculations (Tables 4 and 5). Results for systolic pressures only are shown, the pattern for diastolic pressures being similar. Blood pressures were similar for patients on beta-blockers or methyldopa, the majority of whom were also taking a diuretic. Poor pressure control was judged by levels over 170 systolic. This was seen twice as frequently in patients taking adrenergic neuroneblocking agents as with the other drugs. A similar trend for poorer control with the adrenergic neurone blockers was seen from the average of the latest pressures recorded on these drugs (Table 6).

Table 4 Blood pressure control and drug treatmentpreviously untreated patients

\begin{tabular}{|c|c|c|c|c|c|}
\hline \multicolumn{2}{|c|}{$\begin{array}{l}\text { Drugs alone or in } \\
\text { combination }\end{array}$} & Diuretic & $\begin{array}{l}\text { Methyl- } \\
\text { dopa }\end{array}$ & $\begin{array}{l}\text { Beta- } \\
\text { blocker }\end{array}$ & $\begin{array}{l}\text { Guanethidine } \\
\text { bethanidine| } \\
\text { debrisoquine }\end{array}$ \\
\hline \multicolumn{2}{|l|}{ No. } & 198 & 58 & 97 & 17 \\
\hline \multicolumn{2}{|c|}{$\begin{array}{l}\text { Pressure range } \\
\text { systolic }(\mathrm{mmHg})\end{array}$} & \multicolumn{4}{|c|}{ Percentage in each pressure range } \\
\hline \multirow[t]{2}{*}{$<140$} & $\begin{array}{l}\text { Pre- } \\
\text { treatment }\end{array}$ & 7 & 3 & 5 & 6 \\
\hline & Latest & 44 & 48 & 39 & 41 \\
\hline \multirow[t]{2}{*}{$140-169$} & $\begin{array}{l}\text { Pre- } \\
\text { treatment }\end{array}$ & 38 & 26 & 37 & 35 \\
\hline & Latest & 44 & 40 & 50 & 35 \\
\hline \multirow[t]{2}{*}{$170-199$} & $\begin{array}{l}\text { Pre- } \\
\text { treatment }\end{array}$ & 36 & 40 & 33 & 24 \\
\hline & Latest & 12 & 10 & 10 & 18 \\
\hline \multirow[t]{2}{*}{$\geqslant 200$} & $\begin{array}{l}\text { Pre- } \\
\text { treatment }\end{array}$ & 20 & 31 & 25 & 35 \\
\hline & Latest & 1 & 2 & 1 & 6 \\
\hline
\end{tabular}

Note: Higher proportion of patients with latest pressure over $170 \mathrm{mmHg}$ systolic on guanethidine/debrisoquine or bethanidine compared with others.
CHOICE OF ANTIHYPERTENSIVE DRUGS IN PREVIOUSLY UNTREATED PATIENTS

In 284 previously untreated patients, 67 per cent received diuretics as first choice, or 'first choice equal', 20 per cent methyldopa, 18 per cent a betablocker, 6 per cent guanethidine, debrisoquine, or

Table 5 Blood pressure control and drug treatmentpreviously treated patients

\begin{tabular}{|c|c|c|c|c|c|}
\hline \multicolumn{2}{|c|}{$\begin{array}{l}\text { Drugs alone or in } \\
\text { combination }\end{array}$} & Diuretic & $\begin{array}{l}\text { Methyl- } \\
\text { dopa }\end{array}$ & $\begin{array}{l}\text { Beta- } \\
\text { blocker }\end{array}$ & $\begin{array}{l}\text { Guanethidine/ } \\
\text { bethanidine/ } \\
\text { debrisoquine }\end{array}$ \\
\hline \multicolumn{2}{|l|}{ No. } & 660 & 267 & 401 & 132 \\
\hline \multicolumn{2}{|c|}{$\begin{array}{l}\text { Pressure range } \\
\text { systolic }(\mathrm{mmHg})\end{array}$} & \multicolumn{4}{|c|}{ Percentage in each pressure range } \\
\hline \multirow{2}{*}{$<140$} & On & 15 & 13 & 14 & 12 \\
\hline & Latest & 35 & 32 & 35 & 21 \\
\hline \multirow{2}{*}{$140-169$} & $\begin{array}{l}\text { On } \\
\text { referral }\end{array}$ & 31 & 29 & 30 & 32 \\
\hline & Latest & 44 & 45 & 44 & 39 \\
\hline \multirow{2}{*}{ 170-199 } & $\begin{array}{l}\text { On } \\
\text { referral }\end{array}$ & 30 & 35 & 29 & 32 \\
\hline & Latest & 15 & 17 & 16 & 27 \\
\hline \multirow{2}{*}{$\geqslant 200$} & $\begin{array}{l}\text { On } \\
\text { referral }\end{array}$ & 25 & 23 & 26 & 24 \\
\hline & Latest & 5 & 7 & 5 & 13 \\
\hline
\end{tabular}

Note: Poorer blood pressure control of guanethidine/debrisoquine/ bethanidine.

Table 6 Drug treatment and blood pressure control in previously treated patients

\begin{tabular}{|c|c|c|c|c|}
\hline Drug in last three months & \multicolumn{3}{|c|}{$\begin{array}{l}\text { Latest } \\
\text { blood pressure } \\
\text { (mmHg) }\end{array}$} & $S D N$ \\
\hline \multirow{2}{*}{ Diuretic alone } & $145 \cdot 7$ & & 20 & \multirow{2}{*}{114} \\
\hline & $\overline{92.6}$ & \pm & $\overline{9}$ & \\
\hline \multirow{2}{*}{ Beta-blocker plus diuretic } & $148 \cdot 2$ & & 30 & \multirow{2}{*}{237} \\
\hline & 94 & \pm & $\overline{13}$ & \\
\hline \multirow{2}{*}{ Beta-blocker alone } & $153 \cdot 7$ & & 36 & \multirow{2}{*}{36} \\
\hline & $\overline{95 \cdot 1}$ & \pm & $\overline{16}$ & \\
\hline \multirow[b]{2}{*}{ Methyldopa plus diuretic } & $150 \cdot 8$ & & 26 & \multirow[b]{2}{*}{180} \\
\hline & $\overline{93.9}$ & \pm & $\overline{13}$ & \\
\hline \multirow{2}{*}{ Methyldopa alone } & $149 \cdot 2$ & & 25 & \multirow{2}{*}{34} \\
\hline & $95 \cdot 8$ & \pm & $\overline{13}$ & \\
\hline \multirow{2}{*}{$\begin{array}{l}\text { Guanethidine/bethanidine/debrisoquine } \\
\text { plus diuretics }\end{array}$} & 160.5 & & 28 & \multirow{2}{*}{61} \\
\hline & $97 \cdot 7$ & & 13 & \\
\hline \multirow{2}{*}{$\begin{array}{l}\text { Guanethidine/bethanidine/debrisoquine } \\
\text { alone }\end{array}$} & $162 \cdot 1$ & & 37 & \multirow{2}{*}{18} \\
\hline & $94 \cdot 9$ & & 15 & \\
\hline
\end{tabular}


bethanidine, and 5 per cent other hypotensive agents. There was no change in the preference for diuretics between 1971 and 1975, whereas during that period the use of beta-blockers as first choice increased from 9 to 23 per cent, and that of the adrenergic neurone blockers fell from 12 to zero per cent. When first and second choice drug preferences were combined, by 1975, 45 per cent of patients received beta-blockers, 27 per cent methyldopa, and 4 per cent adrenergic neurone blockers. Ninety-five per cent of the patients treated with beta-blockers at hospital received propranolol.

The main differences between the two larger clinics were a greater preference for methyldopa at one (35\% as first choice 1975), compared with the other, where beta-blockers were more often first choice $(29 \%)$ and methyldopa was used initially in only 9 per cent of cases. Bendrofluazide was used as first or second choice antihypertensive $(36 \%)$ at one of the clinics compared with only 1 per cent in the other, where Moduretic (29\%) or Navidrex K $(25 \%)$ were more often prescribed.

\section{PRESCRIBING BY GENERAL PRACTITIONERS} Most of the drugs being taken at the time of referral of the 817 previously treated patients were prescribed by their general practitioners. Of these patients, 55 per cent were taking diuretics, 35 per cent methyldopa, 17 per cent guanethidine, bethanidine, or debrisoquine, 14 per cent betablockers, 3.7 per cent clonidine, and 3.3 per cent reserpine. Between 1971 and 1975 there was a fourfold increase in the use of beta-blockers, from 6.1 to 24.8 per cent of referred patients, while the use of adrenergic neurone-blocking agents fell from $22 \cdot 3$ to 13 per cent of patients.

\section{CESSATION OF DRUGS IN 'PREVIOUSLY UNTREATED PATIENTS'}

The proportion of patients stopping a drug and not restarting a drug from the same group was calculated for drugs given as first choice, and first choice equal or second to a diuretic. A similar analysis was carried out for diuretics given as first choice or first choice equal, with separate calculations for patients only given diuretic therapy. The chances of continuing on a drug of a particular group ranked in the order diuretic $>$ beta-blockers $>$ methyldopa $>$ clonidine $>$ sympathetic neurone-blocking agents (Table 7 ).

In previously treated patients this analysis was also carried out for antihypertensive drugs being taken on referral, and for drugs prescribed as first choice in the clinic (Table 7). The figures were similar to those for previously untreated patients, except for beta-blockers, which were stopped in fewer patients.
Table 7 Patients stopping a drug permanently

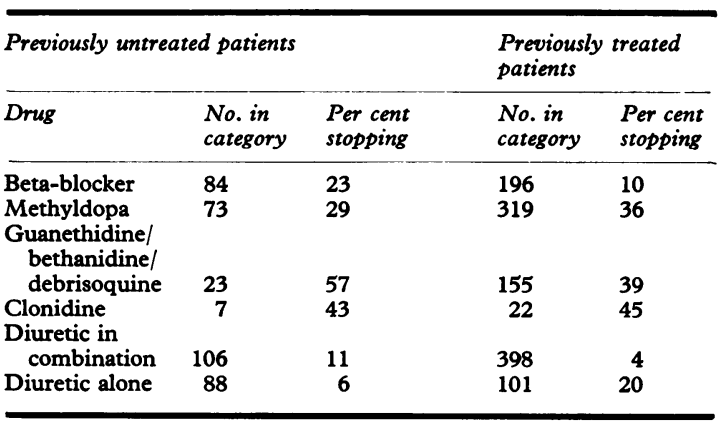

SINGIE AND MULTIPLE DRUG TREATMENT The number of different antihypertensive drugs taken either on discharge or at the most recent visit was calculated for 'previously untreated' and 'previously treated' patients (Tables 8 and 9), respectively. Patients dying or lost to follow-up were excluded from the analysis. With both 'previously treated' and 'previously untreated' groups combined, there were 806 patients; and of these $54(7 \%$ of total population) stopped treatment. Two hundred and thirty-six patients were taking one drug only,

Table 8 Frequency of drug combinations in previously untreated patients

\begin{tabular}{llll}
\hline $\begin{array}{l}\text { Therapy at most recent clinic } \\
\text { visit }\end{array}$ & $\begin{array}{l}\text { For } \\
\text { patients } \\
\text { discharged } \\
(n=84) \\
(\%)\end{array}$ & $\begin{array}{l}\text { For } \\
\text { patients not } \\
\text { discharged } \\
(n=130) \\
(\%)\end{array}$ & $\begin{array}{l}\text { Total } \\
(n=214)\end{array}$ \\
\hline (1) No treatment & 11 & 1 & $(\%)$ \\
(2) One drug & 58 & 48 & 5 \\
(3) Two drug combinations & 29 & 37 & 34 \\
(4) Single diuretic plus two & 2 & 12 & 8 \\
(5) Other drugs & - & - & -1 \\
(6) $>$ Ther three drug & - & 2 & \\
\hline
\end{tabular}

Table 9 Frequency of drug combinations in previously treated patients

\begin{tabular}{llll}
\hline $\begin{array}{l}\text { Treatment at most recent clinic } \\
\text { visit }\end{array}$ & $\begin{array}{l}\text { For } \\
\text { patients } \\
\text { discharged } \\
(n=298) \\
(\%)\end{array}$ & $\begin{array}{l}\text { For } \\
\text { patients not } \\
\text { discharged } \\
(n=294) \\
(\%)\end{array}$ & $\begin{array}{l}\text { Total } \\
(n=592)\end{array}$ \\
\hline (1) No treatment & 12 & 2 & $(\%)$ \\
(2) One drug & 26 & 17 & 7 \\
(3) Two drug combinations & 44 & 48 & 46 \\
(4) Single diuretic plus two & 12 & 19 & 15 \\
$\quad$ other drugs & 12 & 8 & 6 \\
(5) Other three drug & 3 & 5 & 4 \\
(6) $>$ Three drug combinations & 3 & & \\
\hline
\end{tabular}


and of these, 65 per cent were on a diuretic, 17 per cent on a beta-blocker, 13 per cent on methyldopa, 3 per cent on clonidine, and 2 per cent on an adrenergic neurone blocker.

The majority of patients were taking two or more drugs simultaneously. The principal two-drug combinations in 308 patients all included diuretics, with either beta-blockers in $170(55 \%)$, methyldopa in $112(36 \%)$, or adrenergic neurone blockers in $26(8 \%)$. Seventy-four patients were taking combinations of three drugs; these all included diuretics and a beta-blocker, with the addition of a vasodilator in $34(46 \%)$, methyldopa in $28(38 \%)$, or an adrenergic neurone blocker in $12(16 \%)$.

\section{TREATMENT OTHER THAN ANTIHYPERTENSIVE} DRUGS

The numbers of patients taking drugs other than antihypertensive agents was calculated, and figures for the more commonly used substances are shown in Table 10. Both prescription and non-prescription remedies are included where these were reported.

\section{Discussion}

Three problems stand out from the analysis of this data, suboptimal control of blood pressure, multiple drug treatment, and frequent changes between classes of drug.

The reasons for poor blood pressure control in approximately 20 per cent of our patients are complex. Three-quarters were referred already taking antihypertensive treatment and in many cases the reason for referral was a poor response to the drugs. The results in this group are probably not typical of the average response of patients treated by family doctors in the community.

Table 10 Drugs other than hypotensives taken during clinic attendance

\begin{tabular}{lll}
\hline Drug or drug group & $\begin{array}{l}\text { No. of patients } \\
\text { (population 1101) }\end{array}$ & $\begin{array}{l}\text { Per cent of } \\
\text { population }\end{array}$ \\
\hline Sedatives and tranquillisers & 426 & 39 \\
$\begin{array}{l}\text { Potassium supplements (separate) } \\
\text { Potassium combined with }\end{array}$ & 333 & 30 \\
$\quad$ diuretics & 458 & 42 \\
Analgesic and antiflammatory & 176 & 16 \\
$\quad$ drugs & 111 & 10 \\
Antidepressants & 96 & 9 \\
Oral contraceptives & 47 & 4 \\
Digoxin & 46 & 4 \\
Weak vasodilators & 37 & 3 \\
Sympathornimetic amines & 29 & 3 \\
Allopurinol or uricosurics & 25 & 2 \\
Appetite suppressants & 24 & 2 \\
Clofibrate & & \\
\hline
\end{tabular}

Note: Some patients would have taken more than one of these different types of drug.
However, even patients who had previously received no treatment showed less than ideal responses.

Failure to take treatment and unacceptable side effects are likely to have been important factors. Persistent hypertension deserves more attention so that strategies to deal with it can be devised. ${ }^{5}$

The major fall in blood pressure occurred during the first three months of treatment but other studies suggest that this may in part have been a result of regression upon the mean and habituation to the circumstances of the clinic rather than a specific pharmacological action of the drugs. Later there was some deterioration in control. Thus, among patients still attending the clinics, 60 per cent of previously untreated patients' pressures were above $140 \mathrm{mmHg}$ systolic after a year on treatment, 13 per cent were over $170 \mathrm{mmHg}$ systolic, and 20 per cent over $105 \mathrm{mmHg}$ diastolic. Poor blood pressure control was more frequent in previously treated patients, despite more complex therapeutic regimens. However, the average referral pressure of these patients already on treatment was $170 / 109$ $\mathrm{mmHg}$, and it seems likely that their pretreatment pressures were substantially higher. The results emphasise that some patients are likely to have poor pressure control despite strenuous efforts by specialist clinics. More effective and, in particular, more tolerable regimens of treatment are still required.

Changes in treatment are often a result of fashion: however, one indication of effectiveness and tolerability is whether a drug is continued or stopped permanently. As many patients were referred because of side effects of treatment or resistance to prescribed treatment, patients who had received no previous antihypertensive therapy were analysed separately. However, the pattern was not very different in the previously untreated and the previously treated patients. When the figures in the two categories of patients (Table 7) are averaged, then overall diuretics appeared the best tolerated drugs, with only 13 per cent of patients stopping them permanently. They were closely followed by the beta-adrenergic blocking drugs, with 14 per cent stopping them permanently. Methyldopa occupied an intermediate position, with 34 per cent of patients starting on it stopping it permanently at some stage in their treatment. The drugs most often stopped permanently were the adrenergic neurone-blocking drugs in 41 per cent of patients, and clonidine in 44 per cent of patients.

The choice of drugs in the clinics was not random but there were wide differences in preference. It is interesting to note that the blood pressure control achieved was almost identical with the different drug regimens. The only exception was the sympathetic neurone-blocking drugs, whose use was 
associated with higher pressures whether the drugs were used alone or in combination. The use of this group of drugs in the clinic was generally reserved for resistant hypertension. During the study, there was an increasing preference shown for betablocking drugs by all three centres and their referring general practitioners. Some influence of the hospitals on local prescribing was suggested by the pattern in which different drugs were used. During the period of this study the policy of most doctors in the clinics was to start treatment with a diuretic and, if this proved ineffective, to add a betablocking agent or methyldopa. If the two-drug combination was inadequate a third would be added, usually the vasodilator hydralazine to the diuretic/ beta-blocker combination, or a beta-blocker or adrenergic neurone blocker to the diuretic/methyldopa treatment. It is a measure of the difficulty of control with single agents that half the patients required more than one drug and a quarter more than two.

An interesting finding was the high proportion of patients who at some time took drugs which do not lower blood pressure but which might affect blood pressure control. Half the patients had taken sedatives, tranquillisers, or tricyclic antidepressants, and a fifth analgesics or anti-inflammatory drugs. Consumption of oestrogen containing contraceptive pills or medicines containing sympathomimetic amines was relatively common. Separate potassium supplements, of doubtful necessity in most hypertensives, were prescribed for nearly a third of patients.

Despite notable advances in the efficacy and tolerability of drugs available to treat hypertension, formidable problems remain for patients seen in hospital practice. Blood pressure control not un- commonly required two or more drugs, and changes in treatment. Blood pressures often remained in a range associated with an increased risk of cardiovascular disease. These aspects of care are important not only for patients presenting with severe hypertensive cardiovascular disease, but also for those in whom evidence for the benefits of life-long drug treatment is less substantial or unproven.

This research was begun with the aid of a grant from the Nuffield Provincial Hospitals Trust and has been continued with a research grant from The Department of Health and Social Security. We are grateful to many colleagues and assistants in the hypertension clinics of the participating hospitals who have taken part in the collection of the clinical information.

\section{References}

${ }^{1}$ Beilin LJ, Bulpitt CJ, Coles EC, et al. Computer-based hypertension clinical records: a co-operative study. Br Med f 1974; 2: 212-6.

${ }^{2}$ Coles EC, Beilin LJ, Bulpitt CJ, et al. An approach to computer processing of clinical data. Comput $\mathcal{F}$ 1976; 19: 104-9.

${ }^{3}$ Bulpitt CJ, Beilin LJ, Coles EC, et al. Randomised controlled trial of computer-held medical records in hypertensive patients. $\mathrm{Br} \mathrm{Med} \mathcal{F}$ 1976; 1 : 677-9.

${ }^{4}$ Dollery CT, Beilin LJ, Bulpitt CJ, et al. Initial care of hypertensive patients. Influence of different types of clinical records. Br Heart $\mathcal{F}$ 1977; 39: 181-5.

${ }^{5}$ Dargie HJ, Dollery CT, Daniel J. Minoxidil in resistant hypertension. Lancet 1971; 2: 515-8.

Requests for reprints to Professor L J Beilin, University Department of Medicine, Royal Perth Hospital, Perth, Western Australia 6000. 